\title{
9 Guðmundur Bergpórsson as Creator and Creation: A Folk Narrative Study of a 17th Century Disabled Poet
}

\author{
Alice Bower
}

\section{Introduction}

Guðmundur Bergpórsson (1657-1705) was one of Iceland's most prominent poets of rimur, an Icelandic genre of poetry often dubbed "metrical romances." Thirteen rímur or rímur cycles written by Guðmundur have been preserved, and a significant amount of poetry attributed to him exists both in manuscript collections and in oral recordings from the 20 th century. With some notable exceptions, rímur are poetic retellings of known stories, often drawing inspiration from the Icelandic, Germanic, or European narrative traditions. The format does not allow for as much personal expression as other types of poetry, as the poet principally assumes the role of narrator. However, in the so-called mansöngvar (sing. mansöngur) of rímur, a poet is able to step outside of this role and address the audience directly, often lamenting his own misfortunes in life and love. It is within this framework that Guðmundur Bergpórsson sometimes alludes to his disability.

Over the past 200 years, a folk legend tradition has existed parallel to the artistic legacy of Guðmundur Bergpórsson. In the legend tradition a greater focus is placed on Guðmundur Bergpórsson's physical disability. These legends can be viewed in light of what has been referred to as the suppression of historical identity, which can harm disabled people in history by reducing their lives to presumed ideas about disability, denying their agency in the process of identity formation and effacing the importance of other elements in their character (O'Toole 2010a, p. 13, 2010b). Of all the legends recorded about Guðmundur Bergbórsson during the 19th and 20th centuries, the tale of how he became disabled through magical means is likely the most well-known. Another tale, about Guðmundur's unsuccessful quest to a dwarf to find a cure for his disability, also appears in multiple sources. Legends about Guðmundur Bergbórsson's disability often incorporate his work as a poet. Commonly associated with the story about how he became disabled is a single verse attributed to him (Árnason 1954-61, p. 453, Gíslason 1947, p. 81-82), while his poem Hugarhægð is referenced in a version of the legend about his journey to a dwarf (Davíðsson 
1978-1980, p. 140). In folklore, Guðmundur Bergpórsson is widely called kraftaskáld, an Icelandic term for a poet whose words are magically charged.

Guðmundur Bergpórsson is by no means the only disabled author to leave a significant impact on Icelandic literary culture, or the only known figure to become the inspiration for legends which portray his physical difference in a supernatural or tragic light. The sheer quantity and quality, however, of sources written by Guðmundur Bergpórsson which at times allude to his own life, provides the modern researcher with a rare opportunity to compare and contrast his own representations of himself with those formulated by later generations, helping us to gain insights into the process of legend creation which surrounded disability in Icelandic society of the past three centuries.

\section{Guðmundur Bergpórsson’s early years and family background}

Guðmundur Bergpórsson (1657-1705) was born in Vatnsnes in Iceland's North West, one of five children of Porbjörg Guðmundsdóttir (b. 1636) and a man named Bergpór. Among the scant records that exist on his family is a version of the poem Vambarljóð preserved in the manuscript NKS 1894 4 to, in which "a very old woman, the mother of Guðmundur Bergpórsson" is cited as a source (Porgeirsson 2012, p. 182). In the few sources available on Porbjörg Guðmundsdóttir, she appears to have shared her son's interest in literary culture. In Finnur Sigmundsson's introduction to his edition of Olgeirs rímur danska by Guðmundur Bergpórsson, he includes a transcription of a brief biography of the author written in 1770 by Pórður Guðmundsson and Andrés Jónsson, who remember him from their early years. Unfortunately, Finnur does not cite the original manuscript. This account is particularly useful as the authors not only remember interactions with Guðmundur Bergpórsson, but are also well-versed in his poetry and able to connect events in Guðmundur's life to particular works.

Pórður and Andrés describe a good relationship between Guðmundur and his mother. They recall that after Guomundur became disabled at the age of four, he was sent to live elsewhere. He was first at Staðarbakki in Miðfjörður but later migrated west, following his mother who had moved due to poverty. When he was an adult living in Snæfellsnes, his mother would often come to visit him "for her own pleasure" and recite rímur that he had composed as a 12 year old, much to the adult Guðmundur's embarrassment (Sigmundsson 1947, p. 15). Finnur Sigmundsson (1947, p. 22) specifically mentions the poem Vinapökk as a warm expression of Guðmundur Bergpórsson's feelings towards his mother. Vinapökk is preserved in at least six manuscripts, the majority dating from the 19th century. The following discussion is based on my reading of two of these, Syrpa Gísla Konráðssonar from 1850-1870 and Bænir from 1884-1886. Both manuscripts are held at the National and University Library of Iceland under the shelfmarks Lbs 2856 4to and Lbs 2941 8vo, respectively. In the first part 
of Vinapökk, Guðmundur Bergbórsson recalls his life and gives praise to God for the friends and family who have helped him. His account is not without pain, as the sixth stanza tells of how Guðmundur's happy childhood was overset with suffering at around the age of four as he lost almost all his physical strength:

As I spent my childhood as I best could

Blessed God! Who had given me this age

At near four years old

Painful suffering engulfed me

Though I was small

My bodily strength and all of my might (Bergpórsson 1884-1886, 185r). ${ }^{1}$

Up until this point in the poem, he had only described his life and family positively. In stanza five, he refers to the "willing love and friendship of [my] parents." In the seventh stanza, he describes how the devotion of his parents had continued into his adulthood, before proceeding to express gratitude to friends who have helped him. Stanza eleven is likewise dedicated to the virtue and love of his parents (Bergbórsson 1884-1886, 185r, 1850-1870, 119v-120r). Although Guðmundur Bergpórsson refers to both his parents in the above examples, it is noted in Pórður Guðmundsson and Andrés Jónsson's short biography that Guðmundur's father died before Guðmundur reached adulthood and moved west near his mother (Sigmundsson 1947, p. 14). This would indicate that these words of praise would have been most relevant to his relationship with his mother, particularly during his adult years. A later account preserved in Gísli Konráðsson's manuscript Søgupáttr frá Guðmundi skáldi Bergpórssyni (1860, p. 3), held at the National and University Library of Iceland under the shelf mark Lbs 1130 4to, includes more information about Bergbór and references an oral account of a verse allegedly composed by Guðmundur as a child about a mishap suffered by his father at sea. These insights from Guðmundur's poetry into strong family ties, particularly to his mother, are important as they shine a positive light on a relationship which would later emerge as an integral theme in folk narratives about him as it takes on a much darker nature.

\section{Understandings of disability during Guðmundur Bergpórsson's lifetime}

Guðmundur Bergpórsson's works provide valuable insights into the language used and the concepts employed by a 17th century poet when he discusses his own physical impairment. It is nevertheless important to consider his descriptions of life with a disability within the social, cultural, and literary traditions within which he operated. At a first glance, his descriptions 
of his disability and its impact on his life can provide the modern reader with a rather bleak impression of a disabled man's prospects in 17th century Iceland, for example in this lament in the first so-called mansöngur (pl. mansöngvar) of Ótúels rímur:

Of men's strength I have been given

The least of Noah's children

My physical ability does not allow

To make hay, cut crops or row

(Bergpórsson 1952, p. 274).

In the mansöngvar of rímur, a poet is able to step out of their role as a narrator and address the audience directly. Early in the rímur tradition, it had become customary to begin each individual ríma with a mansöngur. Mansöngvar are often formulaic and make use of the same motifs (Ólason 1993, p. 330). Nonetheless, as Sir William Craigie (1952, p. 320) indicates, the originality of a mansöngur is dependent on the poet, with some being able to convey their feelings with a skill that could even possibly be compared to eminent poets of the 17 th and 18 th centuries.

Within the framework of the mansöngur, it is common for poets to complain about misfortunes in their own lives, commonly of a romantic nature. Poets may also draw upon other aspects of their lives and the use of material based on a poet's experience of living with a disability for the traditional lament is not confined to the works of Guðmundur Bergpórsson. Disability in mansöngvar has yet to be thoroughly researched but has not gone unnoticed by scholars of rímur. For example, Björn K. Pórólfsson has drawn attention to the complaint of Rögnvaldur blindi (e. the blind) about his own blindness in Skógarkristsrímur (Pórólfsson 1950, p. 185). In the case of disabled rímur poets, Oliver and Barnes (2012, p. 98) argument, that the personal response of disabled individuals to their impairments "cannot be understood simply as a reaction to 'trauma' or 'tragedy,' but have to be located within a contextual framework that takes account of both history and ideology," can be expanded to cover the stylistic traditions to which they adhere.

The emphasis on Guomundur's own vulnerability seen in the first mansöngur of Ótúels rímur is also to be found in the first mansöngur of the unpublished Bertrams rímur. In stanza 11 he praises God for having supported him for 40 years "so that I neither froze nor starved" (Bergpórsson, p. 1902). This expressed gratitude for his mere survival, placed in the context of his disability, can also be seen in his poem Vinapökk. In the eighth stanza of Vinapökk, Guðmundur expresses gratitude towards those who have housed and clothed him (Bergpórsson 1850-1870, 119v, 1884-1886, $185 \mathrm{v})$. In Guðmundur's own descriptions of his disability, as in later narratives, his age when he became disabled is an important factor. In addition to Vinapökk in which he describes the "painful suffering" which befell him at 
nearly four years old (Bergbórsson 1884-1886, 185r), the final mansöngur of the unpublished Ferakutsrímur, transcribed by Sigmundsson (1947, p. 18), also includes a reference to his age. There he laments his condition which he says he has lived with since the age of four. As will be discussed in further depth in this chapter, narrators of 19th century folkloric texts will use Guðmundur's own references to becoming disabled at aged four to support folk narratives portraying him as a victim of black magic within the home.

In line with the comparatively late establishment of the medical profession in Iceland, understandings of disability developed differently to those in countries which were earlier to industrialise (Smith 2013, p. 93). In pre-industrial Iceland, it was not uncommon for narratives about disability to be framed in a religious or superstitious context. As will be explored further in this chapter, in narratives about Guðmundur Bergbórsson's disability the causes of his physical condition are either unexplained or connected to elusive powers. Nonetheless, certain elements of categorisation which have since been associated with the so-called medical model of disability can be found in narratives about Guðmundur dating back to Pórður Guðmundsson and Andrés Jónsson's 1770 biography. In his analysis of the medical model, the sociologist Tom Shakespeare writes that this approach focuses on physical difference and conceives of disability as the outcome of impairment, as well as being likely to group disabled people in terms of individual impairments (Shakespeare 1996, p. 95). These observations both hold true when narratives about Guðmundur Bergpórsson are studied. Adjectives used to describe him point to a specific impairment rather than a general status as a disabled individual. This appears to have been a common approach in Iceland at the time, as the idea of a disabled community with diverse physical, sensual, and mental differences did not exist as it does today.

Guðmundur Bergpórsson is widely referred to by adjectives that directly reference his impairment, such as visinn, which signifies a condition of physical deterioration. In Pórður Guðmundsson and Andrés Jónsson's biography, more extensive physical descriptions are also to be found in which differences between Guðmundur's body and a preconceived norm are underlined. They write that Guðmundur had "legs as long as an adult man which were both skinny and powerless" (Sigmundsson 1947, pp. 14-15). Here, the authors perception of how legs are supposed to function colours his description of Guðmundur's body, drawing the reader's attention to how it differs. They write that the only part of his body which remained unaffected by his disability was his left arm below the elbow. Everything he wrote was, therefore, written with his left hand (Sigmundsson 1947, pp. 13-15). This description fits particularly well with two key elements of the medical model identified by Shakespeare (1996, p. 95), namely performing and conforming. The observation that Guðmundur was able to write with his left hand is also emphasised in much younger texts, such as Pórarinn Eldjárn's novel Kyrr Kjör (1983, p. 69) and even appears in Finnur Sigmundsson's (1966, p. 49) 
summary of his life and works in an anthology of rímur skálds - a passage which fits onto less than a page. This intrigue with his ability to write is exemplified in Finnur Sigmundsson and Björn K. Pórólfsson's 1947 edition of Olgeirs rímur danska by Guðmundur Bergbórsson, which includes two photographs of Guðmundur's handwriting (Bergpórsson 1947).

In a passage of Pórður and Andrés' biography most likely written by Pórður; a description is to be found of how Guðmundur's condition impacted his ability to take part in daily life on the farm. There we can see that in addition to carving out a role for himself as a teacher and a poet, Guðmundur adapted his physical abilities to fit with the kind of work required of farm inhabitants:

Others told me, that he most often paid to be carried, particularly to church, and those who carried him, as well as ourselves who often carried him, said that he was of a similar weight to a half-grown man. He was good at brass work and woodwork. He did and was able to do all wool production apart from weaving, but he found spinning the hardest, so that was most often done for him by others

(Sigmundsson 1947, pp. 14-15).

The seemingly mundane detail that Guðmundur allowed himself to be carried would later form a crucial part of the legend of his quest to be healed by a dwarf. As is the case with Guðmundur's own references to having been four years old when he became disabled, the inclusion of this detail in legends recorded during the 19th and 20th centuries serves the purpose of endowing them with greater credibility through association with the testimony of Guðmundur Bergbórsson and those who remembered him.

\section{A tale of childhood disability, family ties, and magical healing}

An early folk narrative about Guðmundur's childhood in Pórður Guðmundsson and Andrés Jónsson's 1770 biography betrays supernatural understandings of the nature of disability. In this passage, which Finnur Sigmundsson indicates was written by pórður Guðmundsson, Pórður remembers being taught by Guðmundur Bergpórsson to read at the age of thirteen. He recounts the following story:

He himself recalled, [that] after he became ill in the North, his grandmother advised that he should be put into three hot springs and washed thrice in each of them. After that he improved greatly and his body softened, and never did his disabled condition (ice. visna) or weakness become greater than they had been at that point, so that when he was 14 or 15 years old, he could crawl between farmsteads that were close together

(Sigmundsson 1947, p. 14). 
According to the dates given in Pórður and Andrés' account, Guðmundur Bergpórsson would have moved to Hólsbúd around the late 1690s and stayed there for six years. This means that Pórður's recollection of this story is written around 70 years after he remembered it being told. If this story is to be trusted, it supports other testimonies both in Pórður and Andrés' biography and in Guðmundur's own work of a strong relationship with his family members, particularly women. It would also offer an insight into the attitude of a disabled person towards an experience of a folk medicine practice.

Balneology, the treatment of disease by immersion in baths or mineral springs, appears in a variety of sources spanning cultures and millennia (Shalinsky 1985). In the introduction to her analysis of this practice in the 20th century, the anthropologist Audrey C. Shalinsky (1985, p. 35) connects what she identifies as a "widespread association between life, health and taking in a liquid" to the practice of balneology. She cites folklorist Alan Dundes' analysis of the importance of the wet/dry binary in relation to the evil eye belief system in Semitic and Indo-European cultures. Dundes (1992, p. 298) writes that consequences for the victim of the evil eye tend to involve a drying or withering process. He concludes his analysis by arguing that there is "ample evidence to support the notion that the opposition between wet and dry is a fundamental folk idea, albeit an unconscious one, in Indo-European and Semitic world view, a folk idea which is, metaphorically at any rate, a matter of life and death". With regard to hot spring folk healing practices, Shalinsky $(1985$, p. 35) writes that this method of curing "includes the application of heat in addition to wetness. It is likely that a double binary opposition, wet/dry and hot/cold, underlies Indo-European ideas about health and life."

Shalinsky's application of the binary approach to curing methods using hot springs fits particularly well with Pórður Guðmundsson's narrative, as the Icelandic noun "visna," which I have translated as "disabled condition," is related to the verb "visna," meaning "to wither." In Pórður's account, the bath halted this process. The idea that his body became softer or more relaxed upon receiving this treatment can also be understood in relation to the hot/cold binary, with cold temperatures often being associated with rigidness and frigidity. It is worth noting that the adjective "visinn," also derived from "visna," is used widely to describe Guðmundur's condition, even appearing alongside his occupation as a poet on the 1703 census (Hagstofa Íslands 1924-47, p. 105). Degrees of separation between the informant and the subject of this narrative, as well as the substantial amount of time in between the incident having purportedly taken place, told, and then retold, make it difficult to attribute any greater meaning or value to it than that of a narrative recorded in the latter half of the $18^{\text {th }}$ century. The language used and the elements which the narrator places emphasis on should first and foremost be viewed in the historical and cultural context of Pórður Guðmundsson's lifetime. 
However, if indeed Guðmundur Bergpórsson was brought as a child to three pools in an attempt to reverse or mitigate the effects of his illness, this would not have been the only case of the use of hot springs for medicinal purposes in Icelandic folk culture. In Jónas Jónasson's Íslenzkir pjóðhattir (1961, p. 322), a book on Icelandic folklife compiled during the second decade of the 20th century, the use of dry hot springs is documented as a practice intended to cure rheumatism. While the use of hot springs for medicinal purpose can now be easily identified as a folk healing process as opposed to a scientific one (Shalinsky 1985, p. 34), it is important to consider that this distinction is difficult to apply to Icelandic society of the 17 th and 18th centuries. Medical doctors did not officially practice in Iceland before 1760 and the few medical books that existed were not available to the majority of the population (Jónasson 1961, p. 312-313). This left people such as Guðmundur's family with little alternative to folk cures when illness struck. As the folklorist Laura Stark (2006, p. 315) writes in her analysis of folk healing in early modern Finland, unexpected illness poses a problem for cultural categories of experience as it disrupts the coherence of meaning in everyday life. It is, therefore, conceivable that a family would have sought a supernatural or otherwise unexplained cure for an illness that they most likely could not identify the reason behind.

Whether or not this account of Guðmundur's grandmother's attempt to ward off his illness has any basis in his own lived experience, the tale seems to have resonated to some degree with audiences of the subsequent three centuries. It is recounted in Gísli Konráðsson's manuscript Søgupáttr frá Guðmundi skáldi Bergpórssyni (1860, p. 2) and Ólafur Davíðsson’s Íslenzkar pjóðsögur (1978-1980, p. 139), collected around the turn of the 20th century. More recently, the author Pórarinn Eldjárn included this episode in his novel Kyrr kjör, in which Guðmundur Bergpórsson is the protagonist. Eldjárn (1983, p. 10) has described the novel as fiction which draws on real characters from Guðmundur's life, as well as folktales.

In Eldjárn's retelling of this event, a link is made to another wellknown folk legend about Guðmundur Bergpórsson, as it emerges that Guðmundur's grandmother had obtained her knowledge of this cure in her younger years from dwarfs. With regard to the effect it had on his illness, Eldjárn connects it directly to Guðmundur's ability to write with his left hand. In Kyrr Kjör, Guðmundur says "it was in this way that I gained the strength that I have in my left hand” (Eldjárn 1983, p. 69). By connecting Guðmundur's means of transmitting poetry to the work of dwarfs, Eldjárn evokes mythological connotations of dwarfs as enablers of poetry and wisdom. In Snorri Sturluson's Prose Edda (1998, p. 3), it was the dwarfs Fjalar and Galar who killed Kvasir to make the mead of poetry from his blood. Pórarinn Eldjárn's modern reworking of this story can help to provide an insight into what it is about this tale which has captured the popular imagination for centuries after it allegedly took place. The idea of a remarkable poet being saved at the eleventh hour from an unknown fate by mysterious 
forces perhaps serves to allow readers to approach his works with greater wonder, as lines are blurred between the poet himself and the extraordinary worlds he tells of. The disabled experience, meanwhile, is portrayed as an unexplained misfortune consigned to the realm of miracle-workers. Disability is associated with the magical, creating distance between the societies which tell and consume healing narratives and the reality of disability.

\section{The mother's curse and the dwarf's flight: two 19th century folk legends}

Of the later folk legends about Guðmundur Bergpórsson, the tale of how he became disabled is one of the most widely documented. The earliest published version of this tale appears in Jón Árnason's Íslenzkar pjóðsögur og evintýri, which was first printed in 1862 with a revised edition released in the 1950s (1862-4, p. 468, 1954-1960, p. 453). Interestingly, a detailed description of Guðmundur's physical disability, not dissimilar to that in Pórður Guðmundsson and Andrés Jónsson's 1770 biography, appears in Jón Árnason's manuscript of Íslenskar pjóðsögur og avintýri from 1850-65, which is preserved at the National Library of Iceland under the shelf mark Lbs 529 4to (46v, 49r). This description is absent from the published version, in which the story of how he became disabled through magical means appears first, followed by a short legend about his ability to curse others through his poetry and then a longer narrative about his quest to be healed at the hands of a dwarf. As well as the physical description, additional information on topics such as his life at Arnarstapi, how he became literate, his handwriting, his physical abilities and his work as a teacher is included in Jón Árnason's manuscript (1850-65, 50r-50v), but absent in the published version. As in earlier texts, in the manuscript there is an emphasis on the ways in which Guðmundur was able to adapt his surroundings to give him a better quality of life. This is particularly apparent in the following description of a cart he used for transportation:

And so, he had to either let others carry him or push him in a cart, which was made for this purpose. The morning that the bishop was expected to come to Stapar, Guðmundur had let himself be pushed out in his cart, as looking at nature brought him joy

(Árnason 1850-65, 50v).

The omission of such descriptions in the published anthology could likely be the result of an emphasis placed by the Icelandic collectors and their foreign colleagues on ancient knowledge, as described by the folklorist Terry Gunnell (2010, pp. 22-24). In Íslenzkar pjóðsögur og avintýri, the story of Guðmundur Bergbórsson is reduced to three distinct events, leaving out various episodes relating to his magically charged poetry, amongst which the description of the cart is to be found. Although it is to be expected that 
a large corpus of folktales would be edited and refined for publication, often at the expense of more mundane or biographical details, it is worth considering the effect that such a decision would have had on the image of Guðmundur Bergpórsson in the public imagination.

In the version documented in Íslenzkar pjóðsögur og avintýri of how Guðmundur became disabled, two variants are given. In both, it is a female caregiver who is the cause of Guðmundur's disability:

The poet Guðmundur Bergpórsson was disabled (visinn) on one side as is well known, and it is the testimony of most men that his ill health came about when he was near four years of age and still slept in a cradle by his parents at Stapar, which was then common for children up until the age of six or seven. His mother, who was considered odd in her ways, and his childminder, who was also of ill temperament, exchanged frightening words and curses while the cradle was in between them. Others say that his mother had cursed him and that her words had become magically charged, rendering him a cripple for the rest of his life. In connection with this, Guðmundur widely makes reference in his poetry and in the mansöngvar of his rímur to having been in good health in the beginning of his life and he also appears to scold bad women as if they had done something to deserve it

(Árnason 1954-60, p. 453).

The sources given for this account are the poet Bólu-Hjálmar (1796-1875) and the priest Skúli Gíslason (1825-1888). In Skúli Gíslason's folklore collection (1947, pp. 81-2), the version in which Guðmundur's mother caused his disability by cursing him in a fit of rage is detailed. The motif of the mother cursing her young son is not without precedent in Icelandic narrative tradition, and in Harðar saga ok Hólmverja the protagonist's bad luck is attributed to a curse bestowed upon him by his mother. In Harðar saga (1991, pp. 16-7), as in the tale of Guomundur Bergpórsson, the short description of the curse is followed by a verse, in this case attributed to the mother. In the legend of how Guðmundur became disabled, as will be seen in the tale of his quest to a dwarf, old motifs from the existing narrative corpus are employed by legend narrators. In the case of the mother's curse, the use of this particular motif underlines Guomundur's strong connection with poetry, whilst portraying his disability as the result of black magic.

Both variants of this legend are accompanied by a short verse attributed to Guðmundur Bergpórsson and interpreted as a reference to this event. The feminine plural form of the adjective "gustkaldur" (bitter cold) used in this verse, in the context of being bitter cold or harsh in their words, is particularly interpreted in Íslenzkar pjóðsögur og avintýri to denote a female influence (Árnason 1954-1960, p. 453). This interpretation is also present in Gísli Konráðsson’s manuscript Søgupáttr frá Guðmundi skáldi Bergpórssyni (c. 1860, p. 2). In this source, as well as in Jón Árnason's 
manuscript (1850-65, 49r-49v), a second verse appears which is also connected to this tale, in which Guðmundur allegedly recalls having been healthy in the beginning of his childhood. As can be seen in the published text in Íslenzkar bjóðsögur og avintýri, Guðmundur's own reference to the sudden nature of his disability is presented by narrators of folk legend as evidence of black magic. Here it could be argued that as is the case in legends about changelings, it is the change in an apparently healthy child which sparks connections with magical or hidden powers in the popular imagination (Schoon Eberley 1988, p. 61, Lindow 2008, pp. 216-217). A third variant of this legend was recorded on tape by the folklorists Hallfreður Örn Eiríksson and Svend Nielsen and is held at the Árni Magnússon Institute in Reykjavík under the shelf mark SÁM 84/90. The informant, Kristrún Porvarðardóttir (b. 1873), was from Arnarstapi in Snæfellsnes, the area where Guðmundur spent much of his adult life. In the version she tells, two women were arguing as one of them held Guðmundur. This caused his asymmetrical growth (Porvarðardóttir 1965). While these accounts vary as to exactly who cursed Guðmundur Bergpórsson and whether he was the intended target, they all identify a female culprit within the sphere of the home.

The image of the innocent child cursed with physical impairment conforms to what has since been labelled the "personal tragedy" model of defining disability (Drake 1999, p. 10). In addition to this, the idea of the healthy child rendered disabled by a mother's actions, either during pregnancy or in a child's formative years, is well-documented in folklore. In her analysis of congenital defects in folk belief, Susan Schoon Eberly details two types of explanation for children being born with disability. The first focuses on the conscious and unconscious thoughts of the mother, while the latter involves the mother breaking a taboo (Schoon Eberly 1988, pp. 59-60). In Icelandic pregnancy superstition documented during the 19th and 20th centuries there is also a heavy emphasis on things the mother can do to which cause disability in the unborn child (Jónasson 1961, p. 259). This gendered trope can also be identified in modern discourse on an international level, as the phenomenon sometimes referred to as "mother blame" has been applied to studies on disabled children (Francis 2012, Bell et al. 2009). Writing in a modern context, the sociologist Ara Francis (2012, p. 928) says that "along with mothers who are single, poor, non-White, immigrant, homeless or lesbian, women whose children are 'disabled,' or 'deviant' are frequently judged to be bad mothers." When the scant information that is available to the modern reader on Porbjörg Guðmundsdóttir is taken into account, it appears possible that other elements of her life related to her social status, such as her poverty and becoming widowed early, could have contributed to the process of othering which occurs in folk legends, in conjunction with her son's disability.

It is no surprise that narratives about the magical origins of Guðmundur's disability are often followed by accounts of his search for a magical cure-a 
healing balm owned by a dwarf (dvergur). In Íslenzkar pjóðsögur og avintýri, the following passage is attributed to an Andrés Jónsson, most likely the same man who wrote Guðmundur's biography alongside Pórður Guðmundsson in 1770. The original source quoted is oral in nature, and would likely fill the modern criteria for a "friend-of-a-friend" narrative:

It has been said of a man who was called Andrés Jónsson and lived in Andrésarbúð, close to Hólsbúð where Guðmundur was, that he had said his friends in the north the following story:

"When I was around 20 years of age, I heard Guðmundur say that now there were only two dvergar left in Iceland; one of them lived in a cliff in Langanesströnd and the other was his neighbour and lived in a large stone close to Hólsbúð. He had the balm which could heal him so that he would be healthy again if he could only obtain it, though he suspected that the magic of the curse which had been laid upon him in his innocence would not be easy to shake off." It was one summer on a holy day that most people went to church, apart from Guðmundur who stayed home and Andrés who was with him. Then Guðmundur said to Andrés: "Now I wish to make a deal with you, my friend, as you have proven to me your secrecy and reticence. You must now carry me eastwards from the settlement to the large stone which stands there, to which I will direct you." The boy said that he would do that. They then prepared to leave, and Andrés carried him and put him down opposite the stone which Guðmundur had indicated

(Árnason 1954-60, p. 454).

At the core of this description is the help which Guðmundur received from men such as Andrés with mobility. As has been covered earlier in this chapter, Andrés Jónsson and Pórður Guðmundsson described how he would make deals with able-bodied men to carry him to church, with no reference to the episode in which Guðmundur allegedly asked to be carried to a dwarf's stone. The motif of encounters taking place on holy days between supernatural beings and the person left at the farm while others are at church is common in Icelandic folklore. Unlike in the story of Guðmundur, these legends most commonly take place at Christmas time and a key feature is that the spirits come into the sphere of the home (Gunnell 2002). Nonetheless, the holy timing and consequent absence of others can be understood as an indication that the tale of Guðmundur's quest may be related to this better-known legend tradition.

In the version of the narrative published in Íslenzkar pjóðsögur og avintýri, Andrés Jónsson is asked to leave shortly after placing Guðmundur down by the stone. Before he goes, he is given instructions not to tell anybody of Guðmundur's whereabouts. Later that day, a man came to Hólsbúð looking for Guðmundur, who he believed could cure his daughter of insanity caused by ghosts or evil spirits. Andrés lied that he must have allowed himself to 
be carried to church as he often did. Eventually, Andrés agreed to look for Guðmundur and came across the following scene:

He then walked to the place where he had left Guðmundur and saw that he had lured the dvergur out of his stone and towards his cart with a large box of balm in his hand. The dvergur was so surprised when he saw the man that he disappeared like lightening into his stone, which quickly closed around him

(Árnason 1954-60, p. 454).

In a paper about folk legend and belief on the Snæfellsnes peninsula, Terry Gunnell writes that this legend "takes the form of international migratory legends telling of people unsuccessfully attempting to dig up buried treasure that is protected by some form of enchantment (ML 1810). In each case, the treasure-hunters are disturbed at the last moment by something that distracts their attention." He notes that such legends are relatively common in Iceland, and not least in Snæfellsnes (Gunnell 2020, p. 51). When we consider how other folk narratives about Guðmundur Bergpórsson's life draw heavily from established folk narrative motifs and ideas, Gunnell's observation fits particularly well.

To those familiar with Icelandic folklore, the dwarf's stone as the setting for such a tale might appear unusual. The legend of Guðmundur Bergbórsson is one of only three legends in Íslenzkar pjóðsögur og avintýri featuring dwarfs. While dwarf legends are more common in later folk narrative collections, they are nonetheless still relatively rare. The highest concentration of dwarf legends can be found in the Westfjords and the East. When they do appear, they either play a similar role to elves or hidden people (álfar and huldufólk) or they act similarly to their ancestors in the legendary sagas (Bower 2019). In legendary sagas, dwarfs are presented as gatekeepers, possessors of treasure, folk healers, and magicians. It is in this category that the dwarf allegedly sought by Guðmundur can be placed.

The appearance of a dwarf as the elusive treasure - or facilitator thereof is interesting not least because of the well-established connections between dwarfs and disability. In Icelandic, as in English, the use of the word dwarf to refer to magical creatures or spirits has existed alongside its connotations of physical disability since the middle ages. The first clear use of the word to describe a person of unusually short stature appears in the 13th century kings' saga Morkinskinna, in which a human is said to have been "as short as a dwarf and thick set." The term "til sýnis" (e. on exhibit) is used, indicating that the man was some kind of a court marvel (Unger 1867, p. 94). Subsequently, others have been identified as dvergur in the absence of supernatural characteristics, in particular in translated chivalric sagas such as Erex saga Artuskappa and Ívens saga (Blaisdell 1965, pp. 6-8, Blaisdell 1979, p. 114). 
That having been said, the vast majority of dvergar in medieval and folkloric Icelandic texts preside over supernatural characteristics, either with or without mention of physical difference. In the case of Guðmundur's quest, the dwarf is a supernatural being and is not presented as disabled. However, the connection between dvergar and disability in medieval Icelandic literature and later folk narrative is multifaceted and often extends beyond the dwarf's body. As a healer, the dwarf cures the physically sick and disabled. The use of a healing balm owned by a dwarf for this purpose appears in Göngu-Hrólfs saga (1944, p. 417). Immediately after introducing the balm, its owner Möndull says that he is a dwarf who lives in the earth, and that he possesses "dvergsnáttúra" (e. a dwarf's nature) with regard to medicine and craftsmanship. The dwarf's balm has since cropped up in literature and folk narratives (Laxdal 2006, p. 413-415, Bjarnason and Gíslason 1954-9, p. 91-94).

It is worth noting that narratives about dwarfs who heal tend to focus on sudden illness and disability, often relating to trauma. For example, in Egils saga einhenda ok Ásmundar berserkjabana (1944, p. 174-175), the one-handed Egill seeks a dwarf's help to heal his stump. After doing this, the dwarf makes him a sword which is designed to work as if his arm were whole. Similarly, in the much later folktale of the one-legged shepherd boy, a dwarf restores an amputee's leg (Jónsson 1964-5, p. 195-198). Possibly the earliest example of dwarfs using their craftmanship to restore or compensate for a traumatic physical loss is to be found in Snorri Sturluson's Skáldskaparmál (1998, p. 41), in which they restore the hair of Sif which is cut off by Loki. In all of these narratives, the physical characteristic restored by the dwarf was at one point present, and the loss involved some sort of trauma and/or violence; that is to say, integral to the motif of the dwarf who heals appears to be a patient who was not born disabled, but rather became so at some point in his life. It is, therefore, fitting that in the beginning of the narrative of Guðmundur's quest, he reminds Andrés Jónsson (and by extension the audience), that the curse was laid upon him "in his innocence" (Árnason 1954-60, p. 454). In Jón Árnason's manuscript $(1850-65,50 \mathrm{v})$, the word "áfall," meaning trauma or shock, is also used to refer to Guðmundur's illness.

While the story of Guðmundur Bergbórsson is told in a way that fits comfortably with older saga motifs about disability and healing, the emphasis on his own powers as a folk healer in Íslenzkar pjóðsögur og ævintýri can be harder to put into a pre-established narrative context. They appear to be an extension of his magical abilities as a kraftaskáld and are not prominent in the oldest narratives about Guðmundur. It is very possible that one narrative role played by this attribute is that of tragic irony. This irony, underlining the idea of disability as personal tragedy, is prominent in Jón Árnason's Íslenzkar pjóðsögur og evintýri when it is explicitly stated that he "was just short of being able to use [his skill] to heal his own illness" (1954-60, p. 454). Around 100 years later, it is conveyed in Kristrún 
Porvarðardóttir's oral narrative (1965), which she ends with the words "He was a fine healer, although he couldn't help himself."

\section{Conclusion}

Guðmundur Bergpórsson's prominence as a poet allowed him to play an active role in shaping his own life narrative for future generations. Through his works, he directly addressed his contemporaries and offered a glimpse, if only fleeting, into his own lived experience as a disabled man. In a short biography written over 60 years after his death by two men who had known him as children, droplets of Guomundur's agency in the narrative are still discernible as his poems and memories are referenced. His daily life is detailed in a way that can be humanising, though at the same time influenced by the social attitudes to disability of the era. As time passes from Guðmundur Bergpórsson's death, however, legends begin to form about this distinctive public figure, and it becomes clear that some motifs and ideas have particularly captured the popular imagination. In Jón Árnason's manuscript Lbs 529 4to, written over 150 years after Guðmundur's death, folktales are mixed in with detailed descriptions of Guðmundur's physical appearance and everyday life. Due to what we can only assume were editorial decisions, only three legends about Guðmundur made it into the final publication of Íslenzkar pjóðsögur og avintýri. Of these three, two focus on the cause and possible cure of his disability which are both magical in nature. As well as connecting disability to the supernatural, these two legends play on the tropes of disability as personal tragedy and childhood disability as a result of maternal abuse or negligence. It is these tales which were to leave a profound mark on vernacular narratives of Guðmundur's life well into the 20th and 21st centuries, as the majority of Guðmundur's own poetry remains unpublished.

\section{Note}

1. All translations are the author's own

\section{References}

Árnason, J., 1850-65. Íslenskar pjóðsögur og avintýri. [Manuscript-online] Available at: https://handrit.is/en/manuscript/view/is/Lbs04-0529 [Accessed 05.05.2021]. Lbs 529 4to.

Árnason, J., 1862-4. Íslenzkar pjóðsögur og afintýri. Vol. I-II. Leipzig, DE: J.C. Hinrichs.

Árnason, J., 1954-1960. Íslenzkar pjóðsögur og avintýri. Vol. I-VI. Reykjavík: pjóðsaga.

Bell, K., McNaughton, D., and Salmon, A., 2009. Medicine, Morality and Mothering: Public Health Discourses on Foetal Alcohol Exposure, Smoking Around Children and Childhood Overnutrition. Critical Public Health, 19 (2), 155-170. 
Bergbórsson, G., 1884-1886. Banir: Vinapökk. [Manuscript-online] Available at: https://handrit.is/en/manuscript/view/is/Lbs08-2941 [Accessed 25.05.2021]. Lbs 29418 vo.

Bergpórsson, G., 1902. Rímnakver: Rímur af Bertram. [Manuscript] Held at: Reykjavík: National and University Library of Iceland. Lbs 5070 8vo.

Bergpórsson, G., c. 1850-1870. Syrpa Gísla Konráðssonar: Vinapökk. [Manuscriptonline] Available at: https://handrit.is/en/manuscript/view/is/Lbs04-2856 [Accessed 25.05.2021]. Lbs 2856 4to.

Bergpórsson, G., 1952. Mansöngvar: Ótúels rímur I. In: W. Craigie, ed. Sýnisbók islenzkra rímna. 2nd edition. London: Thomas Nelson and Sons, 273-276.

Bjarnason, A., and Gíslason, O., 1954-1959. Vestfirzkar pjóðsögur. Vol I-III. Reykjavík: Ísafoldarprentsmiðja.

Blaisdell, F., ed., 1965. Erex saga Artuskappa. Copenhagen: Munksgaard.

Blaisdell, F., ed., 1979. Ívens saga. Copenhagen: Munksgaard.

Bower, A., 2019. "Litil fremd er pér pað að brjóta i mér mín stuttu bein": Rannsókn á einkennum, varðveislu og próun dvergasagna á Íslandi frá miðöldum til nútímans. Thesis (MA). University of Iceland.

Craigie, W., 1952. Sýnisbók Íslenskra rímna: Frá upphafi rímnakveðskapar til loka nítjándu aldar: Vol. II. London: Thomas Nelson and Sons.

Davíðsson, Ó., 1978-1980. Íslenzkar pjóðsögur: Bindi 1-4. In: P.M. Jónsson, ed. Reykjavík: Pjóðsaga.

Drake, R., 1999. Understanding Disability Policies. Basingstoke \& London: Palgrave Macmillan.

Dundes, A., 1992. Wet and Dry, the Evil Eye: An Essay in Indo-European and Semitic Worldview. In: A. Dundes, ed. The Evil Eye: A Casebook. Madison, WI: University of Wisconsin Press, 257-312.

Egils saga einhenda ok Ásmundar berserkjabana., 1944. In: G. Jónsson and B. Vilhjálmsson, eds. Fornaldarsögur Norðurlanda 3. Reykjavík: Bókaútgáfan Forni, 153-190.

Eldjárn, P., 1983. Kyrr kjör. Reykjavík: Iðunn.

Francis, A., 2012. Stigma in an Era of Medicalisation and Anxious Parenting: How Proximity and Culpability Shape Middle-Class Parents' Experiences of Disgrace. Sociology of Health and Illness, 34 (6), 927-942.

Gíslason, S., 1947. Sagnakver Skúla Gíslasonar. In: S. Nordal, ed. Reykjavík: Helgafell.

Gunnell, T., 2002. Komi peir sem koma vilja...: Sagnir um innrás óvætta á jólum til forna á íslenska sveitabæi. In: B. Hafstað and H. Bessason, eds. Úr manna minnum: greinar um íslenskar pjóðsögur. Reykjavík: Heimskringla, 191-209.

Gunnell, T., 2010. Daisies Rise to Become Oaks. The Politics of Early Folktale Collection in Northern Europe. Folklore, 121, 12-37.

Gunnell, T., 2020. Invisible Force: The Absence of Folk Legends About Snæfellsjökull. In: M. Egeler and S. Gropper, eds. Dreaming of a Glacier: Snafellsjökull in a Geocritical Perspective. Munich: Utzverlag GmbH, 43-63.

Göngu-Hrólfs saga., 1944. In: G. Jónsson and B. Vilhjálmsson, eds. Fornaldarsögur Norðurlanda II. Reykjavík: Bókaútgáfan Forni, 359-461.

Hagstofa Íslands., 1924-1947. Manntal á Íslandi: Árið 1703. Reykjavík: Ríkisprentsmiðjan Gutenberg.

Harðar saga., 1991. In: P. Vilmundarson and B. Vilhjálmsson, eds. Harðar saga: Íslenzk fornrit XIII. Reykjavík: Hið íslenzka fornritafélag, 1-97. 
Jónasson, J., 1961. Íslenzkir pjóðhattir. Reykjavík: Ísafoldarprentsmiðja.

Jónsson, P.M., 1964-1965. Gríma hin nýja: Safn pjóðlegra fraða islenzkra. Vol. I-V. Reykjavík: Pjóðsaga.

Konráðsson, G., 1860. Søgupáttr frá Guðmundi skáldi Bergpórssyni. [Manuscript] Held at: Reykjavík: National and University Library of Iceland. Lbs 1130 4to.

Laxdal, E., 2006. Ólandssaga. In P. Antonsson and M.A. Porsteinsdóttir, eds.. Reykavík: Háskólaprent.

Lindow, J., 2008. Changelings, Changing, Re-Exchanges: Thoughts on the Relationship Between Folk Belief and Legend. In: T. Gunnell, ed. Legends and Landscape: Articles Based on Plenary Papers Presented at the $5^{\text {th }}$ Celtic-Nordic-Baltic Folklore Symposium, Reykjavík 2005. Reykjavík: University of Iceland Press, 215-234.

O'Toole, M., 2010a. Disability and the Suppression of Historical Identity: Rediscovering the Professional Backgrounds of the Blind Residents of the Hôpital des Quinze-Vingts. In: J. Eyler, ed. Disability in the Middle Ages: Reconsiderations and Reverberations. London: Routledge, 11-24.

O'Toole, M., 2010b. The povres avugles of the Hôpital des Quinze-Vingts: Disability and Community in Medieval Paris. In: M. Cohen and J. Firnhaben-Baker, eds. Difference and identity in Francia and Medieval France. Farnham, UK: Ashgate, 157-174.

Oliver, M., and Barnes, C., 2012. The New Politics of Disablement. Basingstoke, UK: Palgrave Macmillan.

Ólason, V., 1993. Kveðskapur frá síðmiðöldum. In: V. Ólason, ed. Íslensk bókmenntasaga II. Reykjavík: Mál og menning, 283-378.

Schoon Eberley, S., 1988. Fairies and the Folklore of Disability: Changelings, Hybrids, and the Solitary Fairy. Folklore, 99 (1), 58-77.

Shakespeare, T., 1996. Disability, Identity and Difference. In: C. Barnes and G. Mercer, ed. Exploring the Divide. Leeds, UK: The Disability Press, 94-113.

Shalinsky, A., 1985. Thermal Springs as Folk Curing Mechanisms. Folklore Forum, 18 (1), 32-58.

Sigmundsson, F., 1947. Formáli I: Um Guðmund Bergpórsson. In: G. Bergpórsson, ed. Olgeirs rímur danska: Bindi 1. Reykjavík: Landsbókasafn Íslands \& Ísafoldarprentsmiðja, 11-23.

Sigmundsson, F., 1966. Rímnatal I-II. Reykjavík: Rímnafélagið.

Smith, E., 2013. Í skuld við fjölskyldu og Guð. Staða fatlaðs fólks fyrir upphaf læknisfræðilegs skilnings á Íslandi. In: H.B Sigurjónsdóttir, Á. Jakobsson and K. Björnsdóttir, eds. Fötlun og menning: Íslandssaga i öðru ljósi. Reykjavík: Félagsvísindastofnun \& Rannsóknarsetur í fötlunarfræðum, 93-128.

Stark, L., 2006. The Magical Self: Body, Society and the Supernatural in Early Modern Rural Finland. Folklore Fellows Communications, 138 (290), 11-521.

Sturluson, S., 1998. Edda: Skáldskaparmál I. A. Faulkes, ed. London: Viking Society for Northern Research.

Unger, C.R., ed., 1867. Morkinskinna. Christiania, NO: Bentzens.

Porgeirsson, H., 2012. Poetic Formulas in Late Medieval Icelandic Folk Poetry: The Case of Vambarljóð. RMN Newsletter, 4, 181-196.

Porvarðardóttir, K., 1965. Sögn um baklun Guðmundar Bergpórssonar og dverginn i berginu, 21.08.1965. [Audio recording- online] Available at: https://www.ismus. is/i/audio/id-1001377 [Accessed 25.05.2021]. SÁM 84/90 EF.

Pórólfsson, B.K. (1950. Dróttkvæði og rímur. Skírnir, 124 (1), 175-209. 